\title{
Reactions of a $\beta$-Diketiminate Zinc Hydride Complex with Heterocumulenes
}

\author{
Stephan Schulz,* Tamara Eisenmann, Sarah Schmidt, Dieter Bläser, Ulrich Westphal, and Roland Boese \\ Received (in XXX, XXX) Xth XXXXXXXXX 200X, Accepted Xth XXXXXXXXX 200X \\ ${ }_{5}$ First published on the web Xth $X X X X X X X X X 200 X$ \\ DOI: $10.1039 / \mathbf{b 0 0 0 0 0 0 x}$
}

The $\beta$-diketiminate zinc hydride MesnacnacZnH (1) reacts with $\mathrm{CO}_{2}, \mathrm{C}(\mathrm{N} i \text {-Pr })_{2}$ and $t$-BuNCO at ambient temperature with insertion into the $\mathrm{Zn}-\mathrm{H}$ bond and subsequent formation of the 10 corresponding formato (2), formamido (3) and formamidinato (4) complexes.

The effective utilization of abundant, renewable, nontoxic and inexpensive $\mathrm{CO}_{2}$ as $\mathrm{C}_{1}$-feedstock still is an important target in respect to the current enviromental concerns facing our 15 planet.[1] Unfortunately, the high stability of $\mathrm{CO}_{2}$ has limited its use in industrial syntheses, so far, but zinc complexes have been demonstrated in the past to be of potential interest for this purpose. Zinc alkoxide and carboxylate complexes were found to serve as living single-site catalysts for the ring20 opening polymerization (ROMP) of lactide [2] and the copolymerization of epoxides and carbon dioxide [3] yielding biodegradable aliphatic polycarbonates. Moreover, bimetallic calcium/zinc complexes supported by a bridged $\beta$ diketiminate ligand are effective catalysts for 25 terpolymerization reactions of epoxide, cyclic anhydrides and $\mathrm{CO}_{2}$ [4] as well as for epoxide/ $\mathrm{CO}_{2}$ copolymerization.[5]

In order to investigate the mechanism of the $\mathrm{CO}_{2}$ activation in more detail, several reactions of zinc alkoxides RZnOR' and amides RZnNR'2 with $\mathrm{CO}_{2}$ have been investigated 30 experimentally[6] and by theoretical calculations. [7] These reactions typically proceeded with insertion into the $\mathrm{Zn}-\mathrm{N}$ and $\mathrm{Zn}-\mathrm{O}$ bond and subsequent formation of zinc carbamate and carbonate complexes. In addition, pyrazolylborate zinc hydrides were found to react with $\mathrm{CO}_{2}$ and heterocumulenes 35 such as $\mathrm{CS}_{2}$ and isothiocyanates RNCS with insertion into the $\mathrm{Zn}-\mathrm{H}$ bond and formation of the mononuclear $\mathrm{Zn}$ complexes, [8] wheres no reaction was observed with cyclohexyl carbodiimide.[9] Very recently, Driess et al. reported on the formation of zinc formates via Li-promoted 40 hydrogenation of $\mathrm{CO}_{2}$ using heterobimetallic hydridozinc alkoxide clusters of the type $\left[(\mathrm{HZnO} t-\mathrm{Bu})_{4-\mathrm{n}}(\mathrm{LiO} t-\mathrm{Bu})_{\mathrm{n}}\right](\mathrm{n}=$ $0-3)$. Li ions were found to play a distinguished role on the activity of the $\mathrm{Zn}-\mathrm{H}$ moiety since $\left[(\mathrm{HZnO} t-\mathrm{Bu})_{4}\right]$ only showed a very low hydride transfer (reduction) activity of $\mathrm{CO}_{2}$ at $\mathrm{Zn}$ ${ }_{45} \mathrm{H}$ sites whereas $\left[(\mathrm{HZnO} t-\mathrm{Bu})_{3}(\mathrm{LiO} t-\mathrm{Bu})\right]$ reduces $\mathrm{CO}_{2}$ at atmospheric pressure and ambient temperature with formation of the corrsponding formato complex. In addition, $\mathrm{ZnH}_{2}$ completely failed to react with $\mathrm{CO}_{2}$.[10]

We became only recently interested in organozinc hydrides ${ }_{50} \mathrm{RZnH}$ and reported on the synthesis of MesnacnacZnH (1) (Mesnacnac $\left.=\left[\mathrm{HC}\left\{\mathrm{C}(\mathrm{Me}) \mathrm{N}\left(2,4,6-\mathrm{Me}_{3} \mathrm{C}_{6} \mathrm{H}_{2}\right)\right\}_{2}\right]\right)$ containing a sterically demanding $\mathrm{N}, \mathrm{N}^{\prime}$-chelating $\beta$-diketiminato group.[11] 1, which was synthesized according to a procedure established by Harder et al. by reaction of Mesnacnac $\mathrm{ZnCl}$ 55 with $\mathrm{KN}(i-\mathrm{Pr}) \mathrm{HBH}_{3},[12]$ represents one of the rare examples of structurally characterized organozinc hydrides.[13] Even though 1 forms a hydride-bridged dimer in the solid state, pulsed gradient spin echo (PGSE) diffusion measurements at $25^{\circ} \mathrm{C}$ of solutions of $\mathbf{1}$ in different solvents indicated, that $\mathbf{1}$ is 60 monomeric in solution. Herein we report on reactions of $\mathbf{1}$ with $\mathrm{CO}_{2}, \mathrm{C}(\mathrm{N} i-\mathrm{Pr})_{2}$ and $t$-BuNCO.

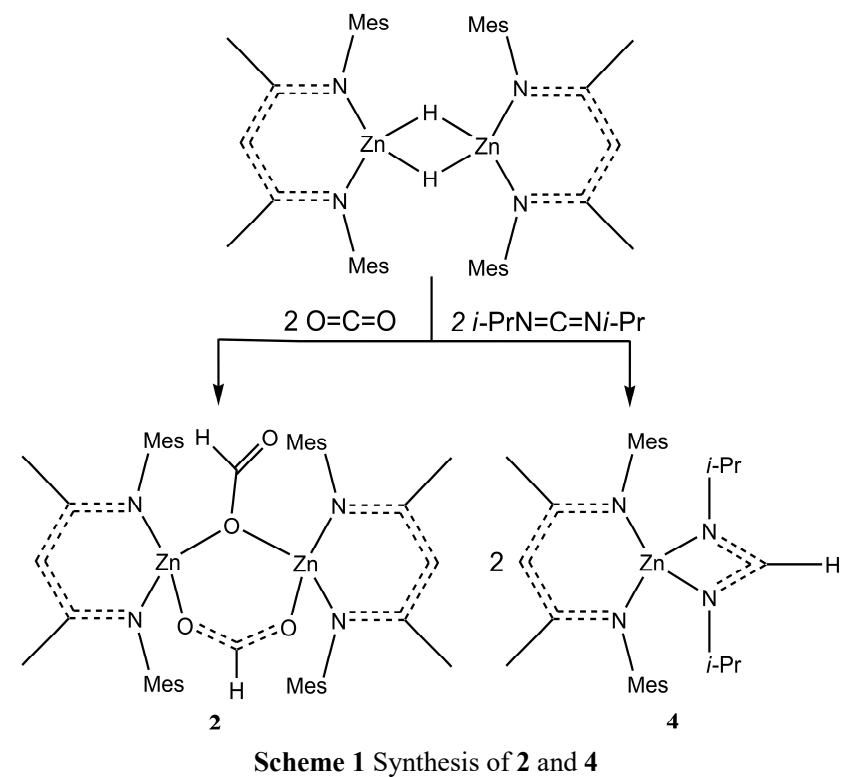

Reaction of 1 with $\mathrm{CO}_{2}$ under very mild reaction conditions 65 (ambient temperature, $\mathrm{CO}_{2}$ under normal pressure) for 2 hours resulted in an in almost quantitative formation of 2 . In situ monitoring of the reaction by ${ }^{1} \mathrm{H}$ NMR spectroscopy showed a continuously decreasing resonance at $4.57 \mathrm{ppm}(\mathrm{Zn}-\mathrm{H})$ and a steadily increasing new singlet at $8.01 \mathrm{ppm}$ due to the 70 formation of the $\mathrm{O}_{2} \mathrm{C}-\mathrm{H}$ group. IR spectra of pure $\mathbf{2}$ shows two absorption bands due to $v_{\text {as }}(\mathrm{CO})$ and $v_{\mathrm{sy}}(\mathrm{CO})$. The difference $\Delta v$ between both is typically used to classify the binding mode of the formiate group, with a large difference of about $200 \mathrm{~cm}^{-}$ 1 indicating a $\eta^{1}$-coordination, whereas difference of $100 \mathrm{~cm}^{-1}$ 75 are typical for bridging and chelating formiate groups. 2 shows a difference of $99 \mathrm{~cm}^{-1}$, which points to a bridging/chelating mode as observed in the solid state structure. No further symmetrical or asymmetrical $\mathrm{CO}$ absorption bands could be identified; however, they might be 80 overlapped by absorption bands of the diketiminato group as a 
comparison of $\mathbf{2}$ with the starting hydride showed (see supporting information file).

The molecular structure of $\mathbf{2}$ in the solid state was investigated by single crystal X-ray diffraction. 2 crystallizes 5 in the triclinic space group $P \overline{1}$ with two molecules in the unit cell. 2 forms an unsymmetrically bridged dimer exhibiting two different coordination modii of the formato unit. The two $\mathrm{Zn}$ atoms are linked by two $\mathrm{HCO}_{2}$ units, with one formato group serving as bridging bidentate (syn-syn) $\mu-\eta^{2}-\mathrm{O}_{2} \mathrm{CH}$ 10 ligand and the second group adopting a bridging $\mu-\eta^{1}$ $\mathrm{OC}(\mathrm{O}) \mathrm{H}$ coordination mode. The presence of only a single resonance for the formato moiety in the ${ }^{1} \mathrm{H}$ NMR spectrum of 2 points to the presence of a monomeric complex in solution as was observed for the starting hydride complex. Moreover, a 15 pulsed gradient spin echo (PGSE) diffusion measurement of a solution of 2 in $\mathrm{C}_{6} \mathrm{D}_{6}$ at $25{ }^{\circ} \mathrm{C}$ yields a hydrodynamic radi of $5.48 \AA$, which is very similar to that observed for monomeric MesnacnacZnH in $\left[\mathrm{D}_{8}\right] \mathrm{THF}(5.26 \AA)$, also indicating 2 to be monomeric in solution. Unfortunately, temperature-dependent ${ }_{20}{ }^{1} \mathrm{H}$ NMR spectroscopic studies were hindered by the extremely low solubility of $\mathbf{2}$ in solvents such as $\left[\mathrm{D}_{8}\right] \mathrm{THF}$ and $\left[\mathrm{D}_{8}\right]$ Toluene at temperatures below $-10^{\circ} \mathrm{C}$.

DFT calculations were performed to evaluate the relative stabilities of monomeric versus dimeric 2. However, the 25 unsymmetrically bridged form as was observed experimentally doesn'r represent an energy minimum. Instead, the symmetrically bridged dimer containing two $\mu-\eta^{2}-\mathrm{O}_{2} \mathrm{CH}$ groups is energetically favored by $24.2 \mathrm{kcal} / \mathrm{mol}$ compared to the monomer (see supporting information file).

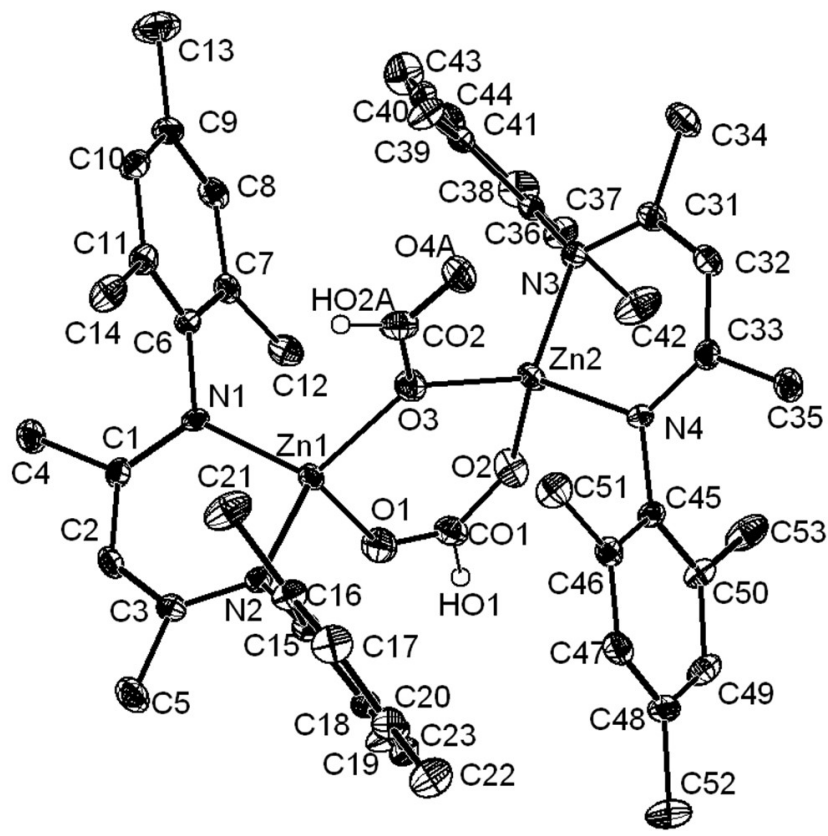

Fig. 1 Solid state structure of 2; $\mathrm{H}$ atoms are omitted for clarity.

The $\mathrm{Zn}-\mathrm{O}$ bond lengths within the bridging bidentate moiety are almost identical (Zn1-O3 1.971(2); Zn2-O3 $1.986(2) \AA)$, whereas the $\mathrm{Zn}-\mathrm{O}$ distances within the $\mu-\eta^{1}$ 35 bridged unit differ by almost $0.04 \AA$ (Zn1-O1 2.039(3); Zn2O2 1.995(3) A). Comparable structural motifs with two metal centers bridged by two formato groups with as-described coordination modii have been previously observed.[14] The $\mathrm{C}-\mathrm{O}$ distances within the formato groups differ significantly. 40 The bridging bidentate moiety (CO1-O1 1.233(4), CO2-O2 1.236(4) $\AA$ ) almost shows equal $\mathrm{C}$-O bond lengths whereas the bridging monodentate unit exhibits a long (CO2-O3 $1.332(5) \AA)$ and a short $\mathrm{C}-\mathrm{O}$ bond $(\mathrm{CO} 2-\mathrm{O} 4 \mathrm{~A} 1.165(7) \AA)$ indicating a terminal $\mathrm{C}=\mathrm{O}$ double bond. Both the terminal $\mathrm{O}$ 45 atom and the $\mathrm{H}$-atom are disordered over two sites ( $\mathrm{SOF} 0.5$ ). The $\mathrm{C}_{3} \mathrm{~N}_{2} \mathrm{Zn}$ rings in 2 are almost planar with the $\mathrm{Zn}$ atoms slightly out of the plane as was observed in [MesnacnacZn $(\mu$ $\mathrm{H})]_{2}$ and the C-C, C-N and $\mathrm{Zn}-\mathrm{N}$ bond lengths within the rings are almost identical compared to the starting zinc hydride 50 complex.[11]

In order to evaluate the reactivity of the zinc hydride in more detail, reactions of $\mathbf{1}$ with heterocumulenes such as $(i-$ $\operatorname{PrN})_{2} \mathrm{C}$ and $t$-BuNCO were investigated. These reactions were also performed at ambient temperature and resulted in an 55 almost quantitative formation of the corresponding formamido (3) and formamidinato (4) complexes, respectively.

Both reactions were monitored by ${ }^{1} \mathrm{H}$ NMR spectroscopy. As was observed for the reaction with $\mathrm{CO}_{2}$, the $\mathrm{Zn}-\mathrm{H}$ resonance of 1 steadily decreased over a period of $30 \mathrm{~min}$ and 60 new resonances at 7.91 (3) and $7.30 \mathrm{ppm}(4)$ occurred.

Colorless crystals of $\mathbf{4}$ suitable for a single crystal structure determination were obtained from a solution in $n$-hexane. 4 crystallizes in the monoclinic space group $P 2{ }_{1} / c$ with four molecules in the unit cell.

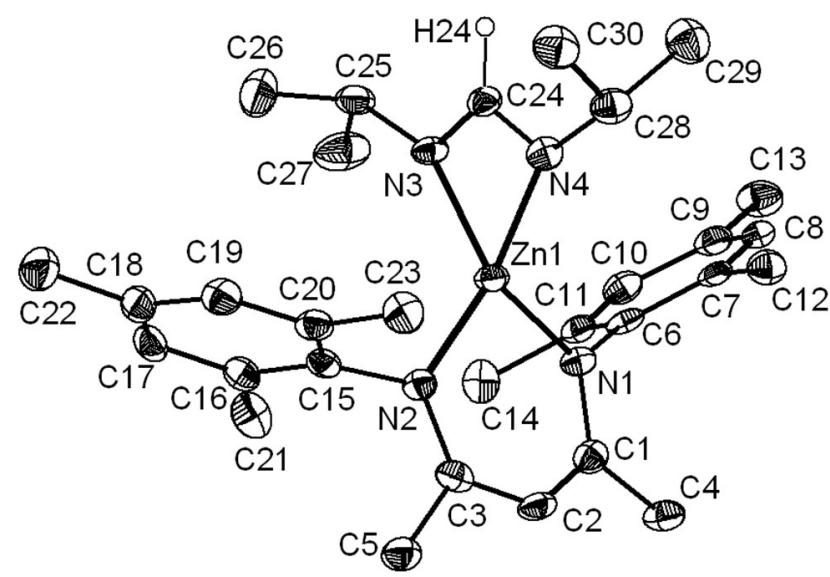

Fig. 2 Solid state structure of $\mathbf{4}$; $\mathrm{H}$ atoms are omitted for clarity

The formamidinato unit serves as chelating $\eta^{2}-(\mathrm{NR})_{2} \mathrm{CH}$ substituent with the $\mathrm{Zn}-\mathrm{N}$ bond lengths significantly differing (Zn1-N3 2.024(3); Zn1-N4 2.092(4) Å), which most likely 70 indicates some sterical stress within this complex. The central $\mathrm{Zn}$ atom adopts a distorted tetrahedral cordination sphere. The endocyclic N1-Zn1-N2 bond angle $\left(97.2(2)^{\circ}\right)$ within the sixmembered $\mathrm{C}_{3} \mathrm{~N}_{2} \mathrm{Zn}$ ring is significantly larger than the N3$\mathrm{Zn} 1-\mathrm{N} 4$ bond angle $\left(65.7(2)^{\circ}\right)$ within the four-membered ${ }_{75} \mathrm{CN}_{2} \mathrm{Zn}$ ring and the $\mathrm{Zn}-\mathrm{N}$ bond lengths within the sixmembered ring are significantly shorter (Zn1-N1 1.968(4); Zn1-N2 1.970(4) $\AA$ ) than in the four-membered ring (Zn1-N3 2.024(3); Zn1-N4 2.092(4) $\AA$ ). The N-C bond lengths of the formamidinato group (C24-N3 1.314(6), C24-N4 1.311(6) $\AA$ ) 80 indicate perfect delocalization of the $\pi$-electrons. As was 
observed for $\mathbf{2}$, the $\mathrm{Zn}$ atom in the $\mathrm{C}_{3} \mathrm{~N}_{2} \mathrm{Zn}$ ring in $\mathbf{4}$ is slightly out of the plane and the $\mathrm{C}-\mathrm{C}, \mathrm{C}-\mathrm{N}$ and $\mathrm{Zn}-\mathrm{N}$ bond lengths within the rings again are almost identical compared to those of the starting zinc hydride complex.

MesnacnacZnH easily reacts with heterocumulenes under very mild reaction conditions and its reactivity is more pronounced compared to the corresponding organomagnesium hydride [DippnacnacMgH $]_{2}$, which was found to react with cyclohexyl carbodiimide $\mathrm{C}(\mathrm{NCy})_{2}$ with insertion into the $\mathrm{Mg}$ -

${ }_{10} \mathrm{H}$ bond whereas the reaction with $t$-BuNCO only gave a mixture of unidentified products.[15] Harder et al. recently reported on the reactions of an organocalcium hydride $[\text { DippnacnacCaH(thf) }]_{2}$ with several unsaturated substrates, but unfortunately no reaction with $\mathrm{CO}_{2}, \mathrm{C}(\mathrm{NR})_{2}$ or RNCO 15 were reported.[16] In contrast, Holland et al. very recently reported on reactions of $\beta$-deketiminato stabilized iron hydrides with both $\mathrm{CO}_{2}$ and $\mathrm{C}(\mathrm{N} i-\mathrm{Pr})_{2}$. These reactions also yielded a formamidinato complex with a chelating $\eta^{2}$ $(\mathrm{NR})_{2} \mathrm{CH}$ unit, whereas the formato complexes showed two 20 bridging bidentate $\mu-\mathrm{O}_{2} \mathrm{CH}$ ligands.[17]

Conclusion. MesnacnacZnH was found to react with $\mathrm{CO}_{2}$ and other heterocumulenes under very mild reaction conditions with insertion into the $\mathrm{Zn}-\mathrm{H}$ bond. Further studies on its reactivity toward other small molecules including other 25 heterocumulenes as well as $\mathrm{C}-\mathrm{C}$ and $\mathrm{C}-\mathrm{X}$ multiple bonded species are currently under investigation.

\section{Notes and references}

University of Duisburg-Essen, Universitätsstr. 5-7, S07 S03 C30, 45117 Essen, Germany. Fax: Int (+)201 1833830; Tel: Int (+)201 1834635; E30 mail: stephan.schulz@uni-due.de

$\dagger$ Electronic Supplementary Information (ESI) available: Experimental procedure, characterization of $\mathbf{2 , 3}$, and $\mathbf{4}$, IR spectroscopic studies as well as computational calculations. See DOI: 10.1039/b000000x/

\pm CCDC 776239 (2) and 776240 (4) contain the supplementary

35 crystallographic data for this paper. These data can be obtained free of charge from The Cambridge Crystallographic Data Centre via www.ccdc.cam.ac.uk/data_request/cif.

A. Name, B. Name and C. Name, Journal Title, 2000, 35, 3523; A. Name, 40 B. Name and C. Name, Journal Title, 2000, 35, 3523.

1 H. Arakawa, M. Aresta, J. N. Armor, M. A. Barteau, E. J. Beckman, A. T. Bell, J. E. Bercaw, C. Creutz, E. Dinjus, D. A. Dixon, K. Domen, D. L. DuBois, J. Eckert, E. Fujita, D. H. Gibson, W. A 45 Goddard, D. W. Goodman, J. Keller, G. J. Kubas, H. H. Kung, J. E. Lyons, L. E. Manzer, T. J. Marks, K. Morokuma, K. M. Nicholas, R. Periana, L. Que, J. Rostrup-Nielson, W. M. H. Sachtler, L. D. Schmidt, A. Sen, G. A. Somorjai, P. C. Stair, B. R. Stults and W. Tumas, Chem. Rev. 2001, 101, 953.

502 M. H. Chisholm, J. C. Gallucci and K. Phomphrai, Inorg. Chem. 2005, 44, 8004; A. P. Dove, V. C. Gibson, E. L. Marshall, A. J. P. White and D. J. Williams, J. Chem. Soc., Dalton Trans. 2004, 570; L. R. Rieth, D. R. Moore, E. B. Lobkovsky and G. W. Coates, J. Am Chem. Soc. 2002, 124, 15239; M. H. Chisholm, J. C. Huffman and K. Phomphrai, J. Chem. Soc., Dalton Trans. 2001, 222; B. J. O'Keefe, M. A. Hillmeyer and W. B. Tolman, J. Chem. Soc., Dalton Trans. 2001, 2215; M. Cheng, A. B. Attygalle, E. B. Lobkovsky and G. W. Coates, J. Am. Chem. Soc. 1999, 121, 11583. For a review article see: J. Wu, T.-L. Yu, C.-T. Chen and C.-C. Lin, Coord. Chem. Rev. 2006, 250, 602 .

3 D. R. Moore, M. Cheng, E. B. Lobkovsky and G. W. Coates, J. Am. Chem. Soc. 2003, 125, 11911; D. R. Moore, M.Cheng, E. B. Lobkovsky and G. W. Coates, Angew. Chem., Int. Ed. 2002, 41,
2599; M. Cheng, D. R. Moore, J. J. Reczek, B. M. Chamberlain, E. B. Lobkovsky and G. W. Coates, J. Am. Chem. Soc. 2001, 123, 8738; M. Cheng, N. A. Darling, E. B. Lobkovsky and G. W. Coates, J. Chem. Soc., Chem. Commun. 2000, 2007; M. Cheng, E. B. Lobkovsky and G. W. Coates, J. Am. Chem. Soc. 1998, 120, 11018; B. Y. Liu, C. Y. Tian, L. Zhanq, W. D. Yan and W. J. Zhanq, J. 70 Polym. Sci. Part A: Polym. Chem. 2006, 44, 6243; M. Kröger, C. Folli, O. Walter and M. Döring, Adv. Synth. Cat. 2006, 348, 1908.

4 R. C. Jeske, J. M. Rowley and G. W. Coates, Angew. Chem., Int. Ed. 2008, 47, 6041

5 D. F.-J. Piesik, S. Range and S. Harder, Organometallics 2008, 27, 6178

6 Y. Tang, W. S. Kassel, L. N. Zakharov, A. L. Rheingold and R. A. Kemp, Inorg. Chem. 2005, 44, 359; J. Notni, S. Schenk, H. Görls, H. Breitzke and E. Anders, Inorg. Chem. 2008, 47, 1382; D. Domide, E. Kaifer, J. Mautz, O. Walter, S. Behrens and H.-J. Himmel, Eur. J. 80 Inorg. Chem. 2008, 3177; P. F. Haywood, M. R. Hill, N. K. Roberts, D. C. Craig, J. J. Russell and R. N. Lamb, Eur. J. Inorg. Chem. 2008, 2024; M. B. Hursthouse, M. A. Malik, M. Motevalli and P. O’Brien, J. Chem. Soc., Chem. Commun. 1991, 1690; I. Abrahams, M. A. Malik, M. Motevalli and P. O'Brien, J. Chem. Soc., Dalton Trans. 1995, 1043.

7 H. J. Himmel, Eur. J. Inorg. Chem. 2007, 675.

8 R. Han, I. B. Gorrell, A. G. Looney and G. Parkin, J. Chem. Soc., Chem. Commun. 1991, 717; M. Rombach, H. Brombacher and H. Vahrenkamp, Eur. J. Inorg. Chem. 2002, 153.

909 H. Brombacher, Ph.D. Thesis, University of Freiburg, 2003.

10 K. Merz, M. Moreno, E. Löffler, L. Khodeir, A. Rittermeier, K. Fink, K. Kotsis, M. Muhler and M. Driess, Chem. Commun. 2008, 73

11 S. Schulz, T. Eisenmann, D. Schuchmann, M. Bolte, M. Kirchner, R. Boese, J. Spielmann and S. Harder, Z. Naturforsch. 2009, 64b, 1397.

9512 J. Spielmann, D. Piesik, B. Wittkamp, G. Jansen and S. Harder, Chem. Commun. 2009, 3455

13 A. J. de Koning, J. Boersma and G. J. M. van der Kerk, J. Organomet. Chem. 1978, 155, C5; W. Kläui, U. Schilde and M. Schmidt, Inorg. Chem. 1997, 36, 1598; H. Hao, C. Cui, H. W. Roesky, G. Bai, H.-G. Schmidt and M. Noltemeyer, Chem. Commun. 2001, 1118; Z. Zhu, R. J. Wright, M. M. Olmstead, E. Rivard, M. Brynda and P. P. Power Angew. Chem. Int. Ed. 2006, 45, 5807.

14 W. B. Tolman, A. Bino and S. J. Lippard, J. Am. Chem. Soc. 1989, 111, 8522; W. B. Tolman, S. Liu; J. G. Bentsen and S. J. Lippard, J. Am. Chem. Soc. 1991, 113, 152; A. Escuer, B. Cordero, X. Solans, M. Font-Bardia and T. Calvet, Eur. J. Inorg. Chem. 2008, 5082; R. F. Baggio, P. K. De Perazzo and G. Polla Acta Cryst. 1985, C41, 194; A.Goeta, R.Baggio and D.Stoilova, Vibrational Spectroscopy 2004, 34, 293.

11015 S. J. Bonyhady, S. P. Green, C. Jones, S. Nembenna and A. Stasch Angew. Chem. Int. Ed. 2009, 48, 2973.

16 J. Spielmann, S. Harder Chem. Eur. J. 2007, 13, 8928; J. Spielmann, S. Harder Eur. J. Inorg. Chem. 2008, 1480; J. Spielmann, F. Buch, S. Harder Angew. Chem. Int. Ed. 2008, 47, 9434.

11517 Y. Yu, A. R. Sadique, J. M. Smith, T. R. Dugan, R. E. Cowley, W. W. Brennessel, C. J. Flaschenriem, E. Bill, T. R. Cundari and P. L. Holland, J. Am. Chem. Soc. 2008, 130, 6624. 
This text is made available via DuEPublico, the institutional repository of the University of Duisburg-Essen. This version may eventually differ from another version distributed by a commercial publisher.

DOI: $\quad 10.1039 / \mathrm{C} 0 \mathrm{CC} 01329 \mathrm{C}$

URN: urn:nbn:de:hbz:464-20201104-090808-9

Accepted Manuscript. The final article was published in: Chemical Communications, 2010,46, 7226-7228 and is available at: https://doi.org/10.1039/C0CC01329C

All rights reserved. 